\title{
State Owned Enterprises
}

\section{Diana Biba}

PhD Cand. Tirana European University, Faculty of Law, Business Law

\section{Abstract}

According to OECD (2015), any corporate entity recognized by national law as an enterprise, and in which the state exercises ownership, should be considered as a State-Owned Enterprise (SOE). Although most industrialized economies are characterized by open and competitive markets firmly rooted in the rule of law, with private enterprises as the predominant economic actors yet governments continue to own and operate national commercial enterprises in key industries, making them important actors in the market, in the economy and in the society. The SOEs are an established reality world - wide but how well this reality performs is another question, that needs to be considered case by case. However, it may be concluded that when governed transparently and efficiently, SOEs can play a role in creating fairer, more competitive markets. Thus, in order to maximize their contribution to the economy and the society, SOEs should be productive and efficient.

Keywords: State-Owned Enterprise, privatization, public enterprise;

According to OECD (2015), any corporate entity recognized by national law as an enterprise, and in which the state exercises ownership, should be considered as a State-Owned Enterprise (SOE). This includes joint stock companies, limited liability companies and partnerships limited by shares. While SOEs were once principally engaged in providing basic infrastructure or other public services within their domestic markets, SOEs are increasingly becoming important actors outside their territories (OECD, 2015:12). Most industrialized economies are characterized by open and competitive markets firmly rooted in the rule of law, with private enterprises as the predominant economic actors (OECD, 2015: 11). Despite extensive privatization, governments continue to own and operate national commercial enterprises in key industries (IFC, 2018).

Any government, depending on the political forces that are in charge with the government of a given country, and with their political vision, define the size of the public sector (Llaci, 2012:301). There is no economy without such a sector while there are economies with different levels of the public sector ${ }^{1}$ (Bundo et al., 1997: 51).

\footnotetext{
${ }^{1}$ Quite often state owned enterprises, also called or referred to as government-owned corporations, are easily confused with public companies, or listed companies whose stock is partly owned by a government entity, due to the term public which make them associated with the notion of a "public good". However, the listed companies are owned and operated by private individuals.
} 
In fact, the public sector has been at the center of debates of researchers and schools. Governments worldwide have long established SOEs with a variety of public policy goals such as providing utilities, controlling natural resources etc. The ' 30 and especially the years after the Second World War, marked an important milestone in the history of SOE-s: their number was increasing in many economies, both developed and emerging ones. The motives behind included a wide array of reasons: to reduce the massive unemployment, to boost economic growth, to ensure control over the economy etc. Such trend continued until the '70 and the ' 80. Corruption, inefficient management, excessive workforce in place, inflation and the increase of budged deficit, exposed the government mass failure (Llaci 2012:302). Evidence from the 1970s and 1980s from a number of countries shows that, on average, SOEs have performed poorly relative to private firms, partly because multiple policy goals proved difficult to reconcile (World Bank, 2014: 2).

The lifespan of SEO-s is quite a rollercoaster: the history provides evidence how once privatized sectors, even in countries like France, Greece or Great Britain, are made public again or vice versa. The pressure exerted by the EU on its Member States to privatize large parts of "classic" public enterprises in the postal, telecommunications, transport and energy sectors is well known (Dine, Bletcher, 2016: 238).

The call for privatization was especially a must in the former Easter block countries in the ' 90 in the light of the transformation of both the political and economic systems in place. While in western countries, privatization can be seen as a reform process, in eastern countries like and in our country, privatization is an essential process of a systemic transformation of society as a whole (Pano 2000:158).

As a matter of fact, even nowadays SEO-s are now a tangible reality whose roles seems increasing. They are present as important actors in many economies, often prevalent in strategic sectors such as energy, minerals, infrastructure, utilities etc. Their performance is important to broad segments of the population and to other parts of the business sector. Today they account for over a fifth of the world's largest enterprises as opposed to ten years ago where only one or two SOEs could be found at the top of the league table (OECD, 2018: 4). The World Bank notices that indeed, many SOEs now rank among the world's largest companies, the world's largest investors, and the world's largest capital market players. In many countries, SOEs in strategic industries are increasingly viewed as tools for accelerated development. However, practice has evidenced that the performance of this sector and especially of the state owned companies is weak and cannot be compared to other companies of the private sector (Llaci, 2012:304).

From the ownership point of view, the SOEs may be fully owned by the state ${ }^{1}$, or the ownership may be mixed: that is to say, either the state during the privatization process, remained as a co- owner by holding the majority of the shares (which is quite rare), or kept a small portion

\footnotetext{
${ }^{1}$ According to OECD (2018): Ownership model: Most of the surveyed countries have either adopted a centralised model for state ownership, have established a central holding company for an important portfolio of SOEs, or have established a central co-ordinating agency, often charged with monitoring performance or coordinating governance practices across the SOE sector. Some countries have a highly decentralised system, with the ownership of SOEs being exercised by a multitude of line ministries and no co-ordinating agency in place. (for more please see http://www.oecd.org/corporate/Ownershipand-Governance-of-State-Owned-Enterprises-A-Compendium-of-National-Practices.pdf
} 
of the shares by giving out the majority. The state may act as an owner through ministries in charge, such as ministry in charge for finance or economy, the ministry in collaboration with line ministries, bodies of local or central government etc.

On the other hand, this means that this "owner", the state, the government, the body, (that is a legal entity) is fully entitled to nominate the management of the SOEs and define their objectives as well. The objectives of SOEs are also considered as their major drawback compared to the private companies. The SOEs are subject to many objectives and also obligations which are quite different from the shareholder value maximization point of view the commercial private companies have as a prime objective. The field SOEs operate in, especially when related to limited resources, foreign investments or with high impact on environment etc., unfortunately creates room for corruption and malpractices.

Evidence show that SEOs seems to be the "favored kid" in the family, due to the preferential treatment they may get in terms of subsidies (which is some cases amounts to a kind of "life support" from the state due to their performance), credits etc. From the activity point of view: in some cases, the SEO may hold the monopoly of the services/ products it provides (mainly in utilities areas), or they may lose the entitlement to monopoly once the market is liberalized such as in the case of the postal services (loss of entitlement to being sole universal postal operator), electronic communications etc. The latter cases exposed SEOs to a competitive market while in the same time being state owned companies that abide to different rules to the game, more bureaucracy, which in some cases may clearly become a disadvantage to them to be able to compete in the market. Such may hamper their activity and in the same time affect the quality of their services. But on the other hand, in order to ensure a fair and neutral market, the SOEs should be subject to similar or equal fiscal and regulatory treatment as private enterprises, without having any favorable treatment. In addition, the SOE sector should be transparent enough to provide competing enterprises with a fair overview of the prevailing market conditions (OECD, 2018:230).

The extent to which state-owned enterprises (SOEs) contribute to, or hamper, the competitiveness of an economy depends mostly on two factors: their efficiency and productivity (OECD, 2018:230). SOEs today are under strong pressure to improve their performance. These pressures come various sources, including the need to enhance their competitiveness and that of the economy as a whole, especially in countries where SOEs are major players (World Bank Group, 2014: xxi).

In South East Europe, the SOE performance varies substantially across economies, depending mostly on the quality of public-sector governance and territorial cohesion, as well as on whether or not a given economy has engaged in recent SOE-related reforms (OECD 2018:230).

The '90 as with many other SEE countries, were a milestone to Albania. While inheriting a centralized economy, one of the fastest and most successful steps taken by the Albanian governments in the 90 s was the privatization of state-owned enterprises and the creation of conditions for private sector development (Ciko 1999:3). By then, the privatization is conceived not only as a change of ownership, but as a new alternative that will ensure the effective operation of actions of "market players", private or state, and guarantee legal competition between them (Pano 2000:156). 
Through the privatization process, the government aim the transfer of state rights to private individuals in all its forms property rights, the right of use and the right to development as a pre- condition to the market economy.

The privatization process was initially regulated in 1991, with law no. 7512, dated 10.08.1991 "On sanctioning and protection of private property, free initiative, private activities of independence and privatization" and then further with law no. 8306, dated 14.3.1998, "On the privatization of important sectors of special of the economy". Other laws and bylaws followed afterwards, while almost all sectors of economy underwent the privatization procedure, including the households, banking, telecommunication, etc.

Further, Law No. 7926, dated 20.4.1995, "On the transformation of state enterprises into commercial companies" provided that all state-owned enterprises were to be transformed into joint stock companies or limited liability companies that would operate in accordance with the provisions of the law then in force no. 7638, dated 19.11.1992 "On commercial companies", unless otherwise provided in this law. With regard to governance, joint stock companies were subject to two tier governance systems only with a Supervisory Board. Law No. 7926, dated 20.4.1995, introduced that the SOEs as Limited liability companies would establish a supervisory board as well, which was a novelty not provided in the Law on Commercial Companies.

Today the state-owned company in itself in Albania in its core is subject to commercial law, i.e. Law 9901/2008. The Law in its Article 213 provides that a state-owned company is a commercial company, which conducts commercial activities, of general economic interest, whose shares are owned directly or indirectly by the central government, local government or by other companies, in which companies the local or central government act as founding major shareholder ${ }^{1}$. So, the establishment, organization and functioning of the SOEs in Albania is regulated by the commercial law. Specific provisions related to certain features of the SOEs may be found in their organic laws separately.

Based on the Law 9901/2008, public authorities can use any form of company to pursue their general economic interests (Article 213, point 1). Moreover, Article 213, (1), makes it possible that public authorities can not only establish companies wholly owned by them, but can also play the role of "mother company" [...] to keep a company under control in accordance with their general economic policies (Dine, Bletcher, 2016: 238). SOEs in the form of limited liability company or joint stock company are registered in the Commercial Register with the National Business Center².

\footnotetext{
${ }^{1}$ The definition of public undertakings, according to Article 213, is in line with Article 2 of Directive $723 / 80$ / EEC on the transparency of financial relations between Member States and public undertakings (Dine, Bletcher, 2016: 237).

2 The official web site is https://qkb.gov.al/; the search for the companies having the state as a shareholder, (such as the ministry, the local powers may be performed here; https://qkb.gov.al/kerko/kerko-ne-regjistrin-tregtar/kerko-per-subjekt/
} 
With regard to governance, although the Law 9901/2008 provides on the one and the two tier model, for the SOEs as joint stock companies it is provided the two tier model, with a supervisory board 1 .

In Albania, the ownership function for the majority of SOEs is exercised jointly by the Ministry of Economy's Directorate General for State Property and the relevant line ministries (OECD 2018: 238). The composition, membership and reward of the members of the Supervisory Board are provided in the Decision of the Council of Ministers no. 570, dated 3.10.2018. In Albania, vice ministers, or officials from line ministries or owner - ministry, may and do serve on some SOE boards. The Albanian Government is the sole shareholder in SOEs operating in power and water supply ${ }^{2}$, postal services, mines, etc. while it has shares in other companies operating in telecommunication etc.

Further, the Decision of the Council of Ministers no. 17, dated 16.01.2019, published in the Official Gazette no. 4, dated 18.01.2019 determines the companies that will be considered of 'public interest' due to the business nature, company size or number of employees, irrespective if private or public. This Decision follows the amendments introduced in 2016 to Law no. 10 091, dated 05.03.2009, "On statutory audit and organization of professions of registered accounting expert and the approved accountant". Both laws introduced the status of 'public interest entities' by specifying that these entities shall apply the International accounting and financial reporting standards (IAS/IFRS) and shall be subject to statutory audit on their financial statements.

The SOEs are an established reality world - wide but how well this reality performs is another question, that needs to be considered case by case. Anytime that the economy get worse, calls for protectionism become more frequent (Xhepa, Belortaja, 1997: 47), but this should not be the case for a desperate call. When governed transparently and efficiently, SOEs can correct market failures, improve public service delivery and play a role in creating fairer, more competitive markets. (OECD 2018:232). Different organizations are involved to improve the SOEs performance. The OECD Guidelines on Corporate Governance of State-Owned Enterprises give concrete advice to countries on how to manage more effectively their responsibilities as company owners, in order to make state-owned enterprises more competitive, efficient and transparent. As with any commercial company, even for SOEs creating a level playing field and company governance are of essence. In order to maximize their contribution to the economy and the society, SOEs should be productive and efficient. Defining prioritized clear and measurable objectives is a step to improve their performance together with a higher and efficient transparency and a less "political and burocratic approach" to them with independent management and direction.

\footnotetext{
${ }^{1}$ The Decision of the Council of Ministers no. nr.271, dated 9.5.1998, as amended provided on the template bylaw of the SOEs as joint stock companies. The DCM rules that the governing bodies of the company are: Supervisory Board with a 4-year term and 2. The Directorate with one or several members. In 2007, the DCM was amended to provide a specific bylaw template for the water supplies companies.

${ }^{2}$ According to findings of the State Supreme Audit, the public companies of the energy and water sectors take loans to expand investments, using the state budget as a guarantor, but in most cases they fail to repay loans from their own funds (for more please see https://www.monitor.al/kompaniteshteterore-menaxhim-te-dobet-332-mln-euro-detyrime-buxhetit/
} 


\section{Bibliography}

Legal base:

[1] Law No. 7926, dated 20.4.1995, "On the transformation of state enterprises into commercial companies";

[2] Law no. 7638, dated 19.11.1992 "On commercial companies";

[3] Law no. 9901/2008 "On the merchants and the commercial companies in Albania";

[4] Decision of the Council of Ministers no. nr.271, dated 9.5.1998, as amended;

[5] Decision of the Council of Ministers no. 570, dated 3.10.2018;

[6] Decision of the Council of Ministers no. 17, dated 16.01.2019, published in the Official Gazette no. 4, dated 18.01.2019;

Other:

[1] https://www.oecd-ilibrary.org/docserver/9789264244160en.pdf?expires $=1608238473 \&$ id=id $\&$ accname $=$ guest $\&$ checksum $=6$ E3B $8 D E 85620$ 19A79693D693524F4C2

[2] https://www.monitor.al/kompanite-shteterore-menaxhim-te-dobet-332-mlneuro-detyrime-buxhetit/

[3] OECD, "Competitiveness in South East Europe: a policy outlook 2018: may be found at

[4] https://www.ifc.org/wps/wcm/connect/topics_ext_content/ifc_external_corporate _site/ifc+cg/topics/state-owned+enterprises;

[5] http://www.oecd.org/corporate/Ownership-and-Governance-of-State-OwnedEnterprises-A-Compendium-of-National-Practices.pdf

[6] World Bank. 2014. Corporate Governance of State-Owned Enterprises: A Toolkit. DOI: 10.1596/978-1-4648-0222-5. Washington, DC: World Bank. License: Creative Commons Attribution CC BY 3.0 IGO;

[7] Ciko Ilir, "Roli i të dhënave statistikore në hartimin e politikave të zhvillimit ekonomik nё Shqipëri", Ministria Ekonomisë Publike dhe Privatizimit, may be found here https://www.bankofalbania.org/rc/doc/ilir_111_1_12885.pdf

[8] Llaci Sh., “Qeverisja e korporatave”, Tiranë, 2012, Shtëpia Botuese “Albpaper”, ISBN 978-9928-05-083-0;

[9] Pano Vasi, "Privatizimi dhe efikasiteti i tij në Shqipëri”, Ministria Ekonomisë Publike dhe Privatizimit, may be found here https://www.bankofalbania.org/rc/doc/vasipano_164_1_12918.pdf;

[10] Llaci Sh., Mema F., Pine V., "Pasojat sociale të privatizimit në Shqipwri”, studim, "Friedrich Ebert" Foundation, Tirana 2003

[11] Instituti Ekonomi, Financw, Biznes, "Zhvillimi ekonomik dhe punësimi në Shqipëri”, proceedings of the National Conference of Economic Studies, II, Tirana, 1997; 